\title{
Leather manufacturing by using treated municipal wastewaters
}

Monica Puccini ${ }^{1, *}$, Sandra Vitolo ${ }^{1}$, Maurizia Seggiani ${ }^{1}$, Domenico Castiello ${ }^{2}$

${ }^{1}$ Department of Civil and Industrial Engineering, University of Pisa, Largo Lucio Lazzarino 56126 Pisa, Italy

${ }^{2}$ PO.TE.CO. Scrl - Polo Tecnologico Conciario - Via Walter Tobagi, 3056022 Castelfranco di Sotto - Pisa, Italy

* Corresponding author: email: monica.puccini@unipi.it; phone: +39 0502217888; fax: +39 0502217866 


\section{Leather manufacturing by using treated municipal wastewaters}

Leather processing requires copious amounts of freshwater, approximately between 15 and 20 $\mathrm{L}$ per $\mathrm{kg}$ of raw hide. The possibility of reusing reclamed municipal wastewaters in the leather production assumes a great significance, proving a sustainable solution to the conservation of the groundwater reserves. In the present work, a combination of a membrane bioreactor (MBR) and nanofiltration (NF) membrane processes was investigated for the municipal wastewater reclamation, and their performances were evaluated and designed to meet water quality criteria required by the wet stages of tanning process. Tests were performed in a pilot plant that reproduces a complete activated sludge biologic treatment in which the municipal wastewaters, after the two steps of de-nitrification and nitrification, are treated in a MBR unit and subsequently in a NF membrane system. The feasibility of the reclaimed wastewater in some phases of the tanning process (beamhouse, tanning, retanning, dyeing, fatliquoring) for manufacturing of calf skins was investigated. Several experimental activities have been performed, both on pilot scale and industrial scale, in order to assess the quality of different finished leathers obtained by using the treated wastewater. The results showed that the municipal wastewaters treated by combing MBR and NF met the required quality criteria in terms of total/permanent hardness, $\mathrm{Fe}, \mathrm{Mn}$ and ammonium contents. The quality of the leathers produced both on pilot and industrial scale with and without treated water reuse did not show any significant difference in terms of physical and technical properties and satisfied fully the tannery specifications.

Keywords: wastewaters, leather industry, membrane bioreactor, nanofiltration, tanning process

\section{Introduction}

Italy, with its about 1415 tanneries, is by far the leather sector's most important location in Europe in terms of establishments, employment, production, and turnover [1]. In 2011, sales of Italian leather manufacturing were about $€ 4.9$ billion: this value represents $62 \%$ of the European Union sales and $17 \%$ of the world-wide production [2]. Italian tanneries are located in four regions: Veneto (Arzignano, Zermeghedo and Montebello Vicentino with about 465 companies), Tuscany (Santa Croce sull'Arno and Ponte a Egola with about 615 companies), Campania (Avellino, Solofra, Naples with about 193 companies) and Lombardy (Turbigo, Castano Primo with about 70 
companies) where most of the EU leather sector's operators are concentrated. They transform raw or wet-blue skins into products used for shoes manufacturing (45.1\%), leather goods (20.7\%), upholstery (18.8\%), clothes and gloves (5.7\%), and others (9.7\% ) [2]. Among these, Tuscany leather pole, specifically directed at the high quality shoe industry, represents one of the most important leather pole at national and international level with $28 \%$ of the Italian sales [2].

The tanning industry requires large amounts of water for the leather production, approximately between 30 and $50 \mathrm{~L}$ per $\mathrm{kg}$ of raw hide to finished leather [3]. Tuscany leather pole water consumption is close to $4.7 \cdot 10^{9} \mathrm{~L}$ per year. In the Tuscany leather district, at present the water used is obtained by exploitation of groundwater reservoirs. According to the worldwide employed criteria to evaluate water scarcity [4], the Tuscany (Central Italy) degree of utilization of available water resources, close to $52 \%$, exceeds the threshold limit of $20 \%$ that imposes specific water management policies. In this context, the development of effective solutions that may reduce the exploitation of water resources for industrial purposes has assumed in the Tuscany leather district aspects of urgency.

With reference to the leather industry, different solutions have been studied and proposed to improve its sustainability as far as the water resources conservation is concerned. Besides all measures and strategies to minimize the quantity of water used in the wet stages of the leather production process [5], the reduction of freshwater consumption by the recovery and reuse of water from the exhaust tannery effluents through the implementation of specific treatments (mainly physical/chemical and membrane technologies) inside the tannery have been proposed. Treatments have been suggested either for effluents from specific stages of the tanning process [6-9] or for the global tannery wastewaters [10-11].

In order to meet the expected higher level of sustainability, the Tuscany leather district municipalities, whose local socio-economic life heavily depends on this sector's activity, have developed a complex program of reorganization of the network that will collect and treat the 
municipal and industrial wastewaters of the district in a central plant. The reutilization of the treated municipal wastewaters in the leather tanning process is one of the major objectives of the reorganization program that will allow to reduce greatly the exploitation of the groundwater reserves and improve the sustainability of the leather industry. The collection of municipal wastewaters in a centralized plant coupled with the existing centralized industrial wastewaters plant is designed to collect the high volumes of water requested by the leather district production.

In order to assess the feasibility of substituting the fresh water fed to the wet stages of the tanning process (beamhouse, tanning, retanning, dyeing, fatliquoring) with reclaimed municipal wastewater, a prolonged research work was performed in order to determine the treatments needed to make the treated water quality suitable for its use that included a) long lasting pilot scale municipal wastewater treatments experimental campaigns, b) pilot scale tanning process runs and c) industrial scale leather production tests.

While the results of the research work performed in the phase a) of the project is described in detail in a dedicated publication [12], this paper reports the results of the pilot scale experimental tanning process runs in which the reclaimed water obtained in the wastewater treatments was used to produce bovine upper leather, according to the high quality stringent standards currently requested by the Tuscany leather district. In order to assess the versatility of the reclaimed water use, either chrome or vegetable tanning recipes were tested and the whole cycle (raw hides to finished leathers) was processed. The paper reports the assessment of the physical-mechanical qualities of the finished leathers as well as their technical evaluation.

\section{Process procedures and methods}

\section{Municipal wastewater reclamation pilot scale plant}

The combination of membrane bioreactor (MBR) coupled to membrane processes such as reverse osmosis (RO), nanofiltration (NF) or ultrafiltration (UF) has been successfully applied for advanced 
treatment of municipal wastewater to produce reclaimed water [13-16]. MBR is an innovative technology in which gravity sludge settling of the traditional activated sludge (AS) system is replaced by a membrane separation process such as microfiltration or ultrafiltration [17]. In recent years, this technology has gained popularity as alternative to the traditional AS process for the municipal wastewater reclamation $[18,19]$, due to its high quality effluent and small footprint [20]. Furthermore, the development of submersible suction membranes has reduced the energy intensive nature of such systems, and has expanded its presence in various industrial and domestic wastewater treatment applications [21]. The coupling of membrane solid/liquid separation with activated sludge process offers numerous advantages over conventional biological processes, including effluent suitable for reuse [22], elimination of settling basins [23], and independence of process performance from filamentous bulking or other phenomena affecting settleability [24]. The separation of biomass from effluent by membranes also allows the concentration of mixed liquor suspended solids (MLSS) and sludge residence time (SRT) in the bioreactor to be increased significantly, thus reducing its size for a given sludge [23]. In this last decade, thanks to a significant technological improvement, the wide acceptance of this technology in municipal utilities is becoming a reality.

The objective of the pilot scale reclamation experimental campaign was to investigate the feasibility of applying membrane bioreactor (MBR) and nanofiltration (NF) membrane processes for the municipal wastewater reclamation and reuse in tanning process. As reported in previous studies [3, 4], direct nanofiltration has proved to represent an appropriate and robust technology for reclamation of wastewaters treatment plants effluents, with the production of a high quality permeate, free of bacteria and viruses, low hardness, low organic content and good removal rates for most micro-contaminants.

The municipal wastewater treatment experimental runs were conducted in a pilot MBR-NF plant. In the following, a brief description of the pilot plant is provided, while more details are 
reported in [12]. The schematic flow chart of the pilot plant is shown in the Fig. 1. The specifications of the microfiltration and nanofiltration membranes are summarized in Table 1 . The municipal wastewater effluents coming from the primary sedimentator of the full scale Aquarno activated sludge district wastewater treatment plant (WWTP) (Santa Croce sull'Arno, Tuscany, Italy) were continuosly fed to the MBR at an average rate of about $400 \mathrm{~L} / \mathrm{h}$. The MBR unit reproduces a complete activated sludge biological treatment in which the wastewater, after two steps of de-nitrification (anoxic) and nitrification (aerobic), is treated in a MBR unit to separate effluent from activated sludge. The MBR system consists of four sections: anoxic, aerobic, MF membrane and oxygen removal before recycling connected in a compact structure; the volumes of the different four sections are $2.45,1.7,3.65$ and $1 \mathrm{~m}^{3}$, respectively. The MBR plant was provided by Kubota Corporation (Japan) and the membrane compartment holds $30 \mathrm{~m}^{2}$ of flat-sheet polyethylsulphone (PES) microfiltration membranes. After reaching the steady-state conditions, the MBR permeate was fed to two parallel spiral wound NF modules to produce higher quality water which meets the water quality criteria required for the tanning process. The NF membrane tested was DESAL-DL4040F from GE-OSMOTICS because it is a low fouling membrane, large operating $\mathrm{pH}$ range and high flux. The NF permeate was collected in storage tanks before being used in the pilot and full scale tanning tests and the retentate was purged.

\section{Pilot scale tanning process runs}

The pilot tests were performed in two twin stainless steel drums (1.2 m diameter, $0.8 \mathrm{~m}$ length), loaded with fresh salted calfskins $(12-16 \mathrm{~kg})$, following the procedure schematized in Fig. 2. Each drum was loaded with one hide cut into two sides (left and right) by the backbone. The hides were soaked, limed, delimed, bated, pickled and tanned in parallel applying same recipes, chemical products and under the same process conditions but using groundwater (tap water preliminary softened) in one drum and reclaimed water in the twin one. Afterwards, re-tanning, dyeing and 
fatliquoring were carried out on the right sides using groundwater and on the two left half-hide using treated water. The labels reported in Fig. 2 indicate the type of water used in the early stages (beamhouse, tanning) of the process and in the final stages (retanning, dyeing and fatliquoring); e.g., the label G/G indicates that groundwater has been used in the whole process.

This crossing procedure was applied to different combinations of tanning and retanning, as shown in Table 2, giving a total of sixteen different experimental conditions set-up. This experimental procedure was used to investigate the effect of the water used on the two sides of the same original hide (the twin halves) as well as the effect of the water on the quality of the final crust leathers, differently tanned and retanned. Three replicates of each experimental condition were carried out in order to evaluate the reproducibility of the results.

The same soaking and liming recipes were adopted either for the vegetable or for the chromium tanning, with the exception of the lime dosage that was twice as much in the vegetable tanning in order to promote a higher relaxation of the hide structure and, consequently, a better penetration of the vegetable tannins, characterized by larger dimensions compared with the chromium tanning agent.

As far as the chromium tanning procedure is concerned, chromium tannage followed the deliming and pickling steps in the same float, after drainage of half bath; the chromium tanned hides were retanned according to two different industrial recipes, a vegetalized one and a pure chromium.

The vegetable tanned samples were retanned according to two different recipes: a pure vegetable one and a syntan-based alternative.

The recipes of the single process steps, raw hides to finished leathers, are reported in the Annexes 1-7. All chemicals were commercial grade products purchased from standard local dealers. The recipes reproduce the industrial recipes widely adopted in the Tuscany leather district to produce high-quality small to large-size leather goods, upper shoes, and belts. 


\section{Water reuse tests at industrial scale}

For the tests at industrial scale $4700 \mathrm{~kg}$ of salted calf hides $(12-16 \mathrm{~kg})$ were used. The tests were carried out at a Tuscan tannery specialized in the production of chrome tanned calf leather for men shoes. Wood drums of $2.5 \mathrm{~m}$ diameter and $2.8 \mathrm{~m}$ length with rotation speed 1 to $4 \mathrm{rpm}$ were used for the beamhouse processes, $3 \mathrm{~m}$ diameter and $3.5 \mathrm{~m}$ length ( $3-6 \mathrm{rpm})$ for the tanning stage, and 2 $\mathrm{m}$ diameter and $3 \mathrm{~m}$ length $(15-20 \mathrm{rpm})$ for re-tanning, dyeing and fatliquoring. Each of the raw hides was cut into two sides by the backbone. The left sides were employed to carry out the different processes and operations using groundwater, whereas the right sides were employed to carry the same operations but using treated water obtained in the pilot MBR-NF plant. The different operations were performed in identical drums and machinery for each phase, applying the same formulas, chemical products and under the same working conditions. Therefore, the only difference between each pair of sides produced from the same hides was the type of water used in the process.

The recipe assessed at industrial scale consisted in a chromium tanning followed by pure chromium retanning.

\section{Assessment of leather quality}

The crust leathers obtained were characterized in terms of physical and technical properties. The leather samples for physical testing were cut from the tanned crust leathers according to the official sampling position (IUP2 2000) from each run. Physical tests were conducted according to Italian standards (UNI 10594) for upper leather. The load at tear was determined according to the UNI EN ISO 3377-2 method using an electronic dynamometer (Pegasil, Mod. Marte) which also gives the extension at tear as a secondary output. The extension and load at grain crack were determined according to the UNI EN ISO 3379 (recently converted in UNI 11308) method using a las-tometer (Pegasil, Mod. EL-51E). 
The crust leathers were assessed for hand, softness, fullness, roundness, dye quality , and possible defects by hand and visual examination. The leathers were rated on a scale of $0-5$ for each functional property by two the technical personnel of PO.TE.CO and an experienced tanner; higher scores indicate a better property.

\section{Results and discussion}

\section{Efficiences of the membrane processes}

The Table 3 reports the range of the main characteristics of the fresh groundwaters actually used in the Tuscany leather pole. This table reports also the specifications required for the water to be fed to the wet stages of the tanning process with specific reference to the steps in which the water quality is foundamental to achieve a high-quality leather, such as tanning, retanning, fatliquoring and dyeing. The Table 3 also reports, for comparison, the yearly average characteristics of the effluent of the Aquarno traditional activated sludge WWTP whose capacity is 20,000 equivalent-inhabitants, representative of the water effluents in the leather district area. As shown, the local groundwaters do not meet all the required specifications, particulary in terms of total hardness, iron and manganese. Hard waters are undesirable: collagen softening and deliming in the preparation of hides is hindered. Calcium and magnesium may form insoluble compounds with vegetable and synthetic tannins resulting in incomplete tanning. The uneven deposition of these salts on the hides causes patchiness during dyeing operation. In addition calcium and magnesium may react with dyes and fatliquors reducing their effectiveness in the post-tanning operations. Also iron and manganese interfere in various ways. Iron and manganese can form dark-coloured precipitates during tanning, which subsequently reduce tanning efficiency. In dyeing operations, they may form complexes with dyes, rendering them inactive and resulting in discolouration, colour changes and dulling of shades. To prevent the problems caused by hardness, iron and manganese, the local groundwaters are usually softened and purified from iron and manganese by ion exchange processes prior to being 
used by the tanneries.

As far as the traditional activated sludge WWTP effluent are concerned, COD, TSS, ammonium nitrogen, hardness, phosphates and chlorides are higher than those required.

Table 4 shows the changes of the physical-chemical properties of the MBR feed as it is treated by the MBR-NF system used in this study. The values reported are expressed as mean value \pm standard deviation. As expected, the MBR process was able, at different removal efficiency, to remove COD, TSS, ammonium nitrogen, iron and manganese from the municipal wastewaters. It was not able to remove all other species that do not participate to the biological treatment cycle and can cross the microfiltration membrane, such as monovalent ions (for example, chlorides). However, MBR was able to meet the specifications required only for TSS, iron and manganese; COD and ammonium nitrogen in the MBR permeate still resulted above the maximum allowed. An increase of nitrates in the MBR permeate is explained by the conversion of ammonium nitrogen to nitrates that occurs in the biological treatment cycle.

When compared with the effluent of traditional activated sludge Aquarno WWTP effluent, the MBR permeate shows lower values of COD, TSS and ammonium nitrogen.

The following NF treatment was necessary and effective to further remove COD and ammonium nitrogen below the limits that allows the reuse of the treated water. The NF treatment was able to reduce also the rest of parameters - total hardness, phosphates and chlorides - below the limits.

The result, as a whole, was a highly purified permeate, characterized by values of physicalchemical parameters well below the specified limits requested for its use in the more critical steps of the tanning cycle. 


\section{Water reuse tests in pilot scale runs}

Table 5 and 6 show the physical properties of the final crust leather obtained in the pilot scale tests. The data reported are mean values of at least three determinations. As it can be seen, all samples complied with the standards required for high quality bovine upper leather in terms of tearing load $(>80 \mathrm{~N})$, and load $(>200 \mathrm{~N})$ at grain crack. For the distention at grain crack, the vegetable-tanned leather processed with treated water showed a value of this parameter slightly lower than the limit required from guidelines. Thus, a different behaviour was observed in the chrome-tanned samples respect to the vegetable-tanned samples. This could be related to the mechanism of fixation onto collagen of the tanning agent, mineral or vegetable. It is well known that the excellent tanning power of Chromium (III) is due to its high capability, according to the olation process, to form polymeric oxydrilic-bridged complexes that are allowed to coordinate and crosslink the collagen proteins whose carboxyl groups act as ligands into the chromium complexes themselves. Instead, the polyphenols, components of the tannins, react with collagen proteins to form hydrogen bonding $[25]$.

No significant differences between the final leather samples in terms of technical properties (Table 7 and 8): all the samples were characterized by technical properties comparable with the conventional crust leather and assessed as satisfactory and suitable according to the market request. Thus, the use of treated water in place of the softened tap water in the whole process or in some stages did not involve a decrease in quality of the final leather. In addition, the treated water has an average total hardness of $14^{\circ} \mathrm{F}$ and, hence, it does not need to be softened before being used in the tanning process. This implies savings since water and salt consumption for the regeneration of softener resins is avoided.

\section{Water reuse tests at industrial scale}

Table 9 reports the mean values of the physical and technical properties of the final leathers 
obtained on industrial scale. The results show that the measured parameter values for the left sides produced using softened groundwater $(\mathrm{G} / \mathrm{G})$ and for the right sides using treated water $(\mathrm{T} / \mathrm{T})$ were very similar. All the leathers showed good quality, consistent with the specifications of the tannery. These results validated the feasibility of using the water produced by the MBR-NF system in the different wet stages of the tanning process.

\section{Conclusions}

The results of this study indicate that the combination of MBR-NF processes applied to municipal wastewaters is adequate for recovering water with low hardness $\left(13.6 \pm 5.3^{\circ} \mathrm{F}\right)$, very low Fe and $\mathrm{Mn}(<0.1 \mathrm{mg} / \mathrm{L})$ and ammonium $(<0.1 \mathrm{mgN} / \mathrm{L})$ levels. In order to demonstrate the suitability of the treated water in the tannery processes, leathers from calf hides were manufactured both on pilot and industrial scale using treated water in contrast with the simultaneous production using softened groundwater. Pilot scale tests enabled an easy comparison between twin half-hides processed using softened groundwater and reclaimed water. The pilot-scale tests demonstrated that there were no significant differences between the leathers obtained in terms of physical and technical properties, demonstrating that the quality of the treated water did not involve a decrease in quality. The industrial-scale tests also showed the technical feasibility of using the reclaimed water in all the wet stages of the tanning process (beamhouse, chrome-tanning, re-tanning, dyeing, fatliquoring). The wet-blue leathers produced with and without treated water did not show any considerable differences at sensorial and physical levels and their quality fully satisfied the tannery specifications. In conclusion, the good results of the large scale tests are of great importance, proving an excellent opportunity to implement this municipal wastewater reclamation system and reuse in the tanning process for the preservation of fresh water. 


\section{References}

[1] BREF "Best Available Techniques for the Tanning of Hides and Skins" (2003).

[2] Rapporto Socio-Ambientale. Unione Nazionale Industria Conciaria (UNIC) [Social and environmental report]. National Union of the Tanning Industry. Available from: http://unic.it/.../UNIC/.../Documenti_542_rapporto_socio_ambientale. 2012.

[3] Pathe PP, Suresh Kumar M, Kharwade MR, Kaul SN. Common effluent treatment plant (CEPT) for wastewater management from a cluster of small scale tanneries. Environ Technol. 2004; 25(5): 555-563.

[4] Angelakis AN, Marecos Do Monte MHF, Bontoux L, Asano T. The status of wastewater reuse practice in the Mediterranean basin: Need for guidelines. Water Res. 1999; 33(10): 2201-2217.

[5] Audrey DL, Takashi A. Recovering sustainable water from wastewater. Environ Sci Technol. 2004; 38(11): 201A-208A.

[6] Cassano A, Molinari R, Romano M, Drioli E. Treatment of aqueous effluents of the leather industry by membrane processes: A review. J Membrane Sci. 2001; 181(1): 111126.

[7] Nazer DW, Al-Sa'Ed RM, Siebel MA. Reducing the environmental impact of the unhairing-liming process in the leather tanning industry. J Clean Prod. 2006; 14(1): 6574.

[8] Raghava Rao J, Chandrababu NK, Muralidharan C, Nair BU, Rao PG, Ramasami T. Recouping the wastewater: A way forward for cleaner leather processing. J Clean Prod. 2003; 11(5): 591-599.

[9] Roig J, Font J, Marginet X, Jorba M, Ollé L, Bacardit A, Puig R. Wastewater reutilization in the leather industry using membrane technology. J Am Leather Chem As. 2009; 104(4): 139-148.

[10] Suthanthararajan R, Ravindranath E, Chitra K, Umamaheswari B, Ramesh T, Rajamani S. Membrane application for recovery and reuse of water from treated tannery wastewater. Desalination. 2004; 164(2):151-156.

[11] Fababuj-Roger M, Mendoza-Roca JA, Galiana-Aleixandre MV, Bes-Piá A, CuartasUribe B, Iborra-Clar A. Reuse of tannery wastewaters by combination of ultrafiltration and reverse osmosis after a conventional physical-chemical treatment. Desalination. 2007; 204(1-3): 219-226. 
[12] Seggiani M, Puccini M, Castiello D, Andreanini N, Berni P, Vitolo S. Municipal wastewater reclamation and reuse in the leather industry. Desalin Water Treat. 2014; 52(7-9): 1647-1653.

[13] Raffin ME, Germain E, Judd S. Wastewater polishing using membrane technology: a review of existing installations. Environ technol. 2013; 34(5): 617-627.

[14] Chon K, Sarp S, Lee S, Lee JH, Lopez-Ramirez JA, Cho J. Evaluation of a membrane bioreactor and nanofiltration for municipal wastewater reclamation: trace contaminant control and fouling mitigation. Desalination. 2011; 272(1-3): 128-134.

[15] Dialynas E, Diamadopoulo E. Integration of a membrane bioreactor coupled with reverse osmosis for advanced treatment of municipal wastewater. Desalination. 2009; 238(1-3): 302-311.

[16] Jacob M, Li C, Guigui C, Cabassud C, Levison G, Moulin L. Performance of NF/RO process for indirect potable reuse: Interactions between micropollutants, microorganisms and real MBR permeate. Desal. Wat. Treat. 2012; 46: 75-86.

[17] Ivanovic I, Leiknes TO. The biofilm membrane bioreactor (BF-MBR) - A review. Desal. Wat. Treat. 2012; 37: 288-295.

[18] Liu S, Wang JF, Wang BZ, Wang B, Wan W. Pilot scale study on biological nutrient removal and membrane fouling alleviation in combined membrane bioreactor for municipal wastewater treatment. Adv. Mater. Res. 2011; 365: 354-360.

[19] Li C, Cabassud C, Guigui C. Evaluation of membrane bioreactor on removal of pharmaceutical micropollutants: a review. Desalin Water Treat. 2014; in press; doi: 10.1080/19443994.2014.926839.

[20] Joss A, Baenninger C, Foa P , Koepke S, Krauss M, McArdell CS, Rottermann K, Wei Y, Zapata A, Siegrist H. Water reuse: $>90 \%$ water yield in $\mathrm{MBR} / \mathrm{RO}$ through concentrate recycling and $\mathrm{CO}_{2}$ addition as scaling control. Water Res. 2011; 45: 1641-1651.

[21] Kishino H, Ishida H, Iwabu H, Nakano I. Domestic wastewater reuse using a submerged membrane bioreactor. Desalination. 1996; 106: 115-119.

[22] Melina T, Jefferson B, Bixio D, Thoeye C, De Wilde W, De Koning J, van der Graaf J, Wintgens T. Membrane bioreactor technology for wastewater treatment and reuse. Desalination. 2006; 187: 271-282.

[23] Naddeo V, Rizzo L, Belgiorno V. Water, wastewater and soil treatment by advanced oxidation processes (AOPs). 2010. ASTER Publishing. Italy. 
[24] Hai F I, Yamamoto K. Membrane biological reactors. 2011. In P. Wilderer (Eds.), Treatise on Water Science. Elsevier. UK.

[25] Covington AD. Tanning Chemistry: the science of leather. 2011. RSC Publishing. Cambridge. 


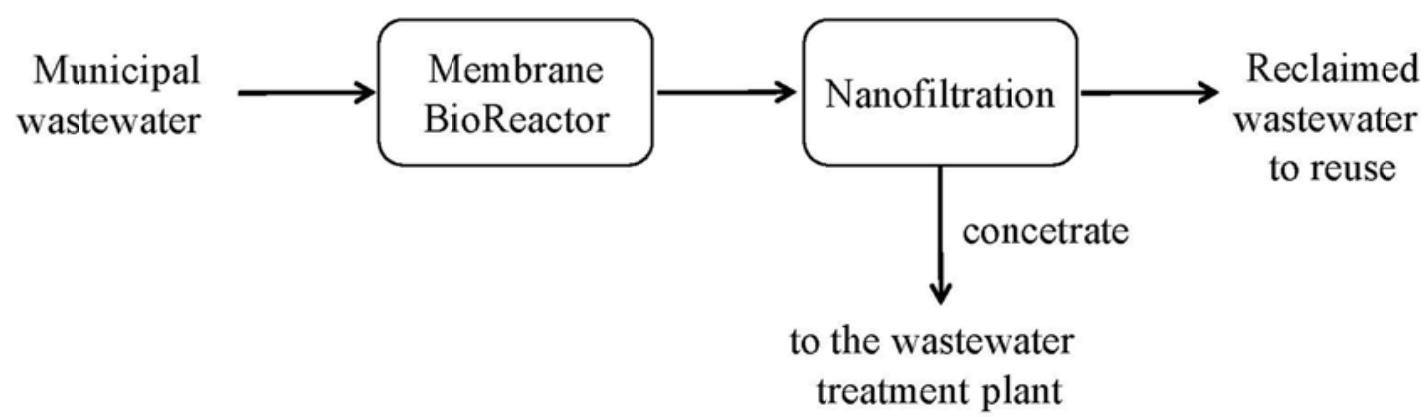

Figure 1. Flow chart of the wastewaters treatment pilot plant

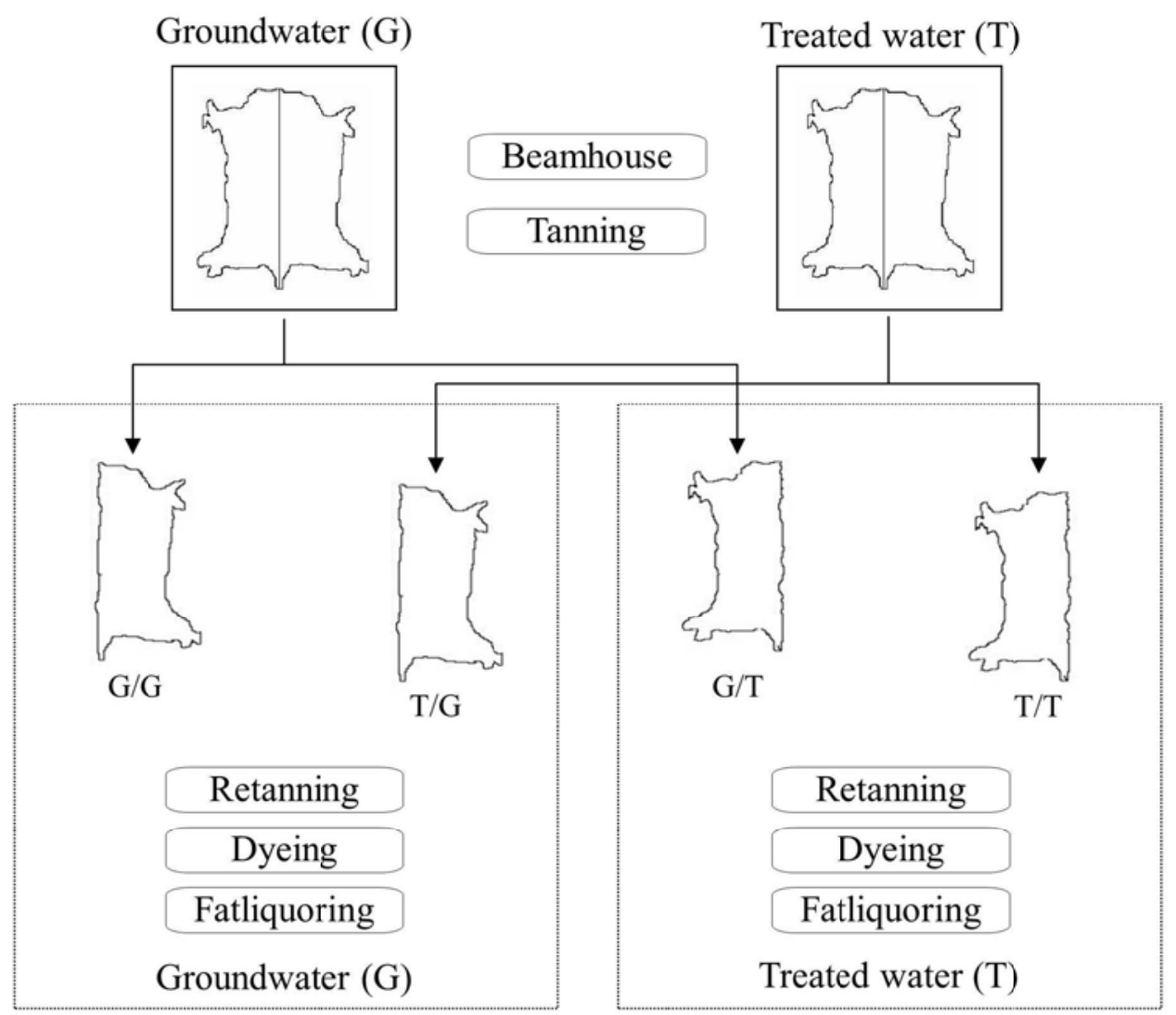

Figure 2. Flowchart of pilot scale tests 
Table 1. Characteristics of the MBR and NF membranes.

\begin{tabular}{lcc}
\hline Characteristic & MBR membranes & NF membranes \\
\hline Manufacter & Kubota Corporation (Japan) & GE-OSMOTICS \\
Materials & Polyethylsulphone (PES) & Aromatic polyamide \\
Total surface area $\left(\mathrm{m}^{2}\right)$ & 30 & 8.36 \\
Pore size $(\square \mathrm{m})$ & 0.4 & 0.001 \\
\hline
\end{tabular}

Table 2. Combinations of the different tanning and retanning processes performed on calfskin.

\begin{tabular}{lccc}
\hline Hide & Tanning & Retanning & Label \\
\hline \multirow{4}{*}{ calfskin } & Chrome & Chrome & CC \\
& Chrome & Vegetable & CV \\
& Vegetable & Vegetable & VV \\
& Vegetable & Syntan & VS \\
\hline
\end{tabular}

Table 3. Characteristics of the fresh groundwaters, specifications for tanning process and the composition range of the Aquarno WWTP effluent.

\begin{tabular}{lccc}
\hline & Groundwater & $\begin{array}{c}\text { Water } \\
\text { specifications }\end{array}$ & $\begin{array}{c}\text { Aquarno WWTP } \\
\text { effluent }\end{array}$ \\
\hline $\mathrm{pH}$ & $7-7.5$ & $6.5-7.5$ & $7.5-8.5$ \\
Conductivity $(\mu \mathrm{S} / \mathrm{cm})$ & $1500-2000$ & $1500-2000$ & $2000-3000$ \\
$\mathrm{COD}(\mathrm{mg} / \mathrm{L})$ & $5-10$ & $<5$ & $80-120$ \\
$\mathrm{TSS}(\mathrm{mg} / \mathrm{L})$ & - & $<5$ & $20-40$ \\
ammonium $\left(\mathrm{N}^{-\mathrm{NH}_{4}}{ }^{+}\right)(\mathrm{mgN} / \mathrm{L})$ & $0.5-2.5$ & $<0.1$ & $<5$ \\
total hardness $\left({ }^{\circ} \mathrm{F}\right)$ & $40-60$ & $10-20$ & $80-120$ \\
phosphates $\left(\mathrm{P}-\mathrm{PO}_{4}{ }^{3-}\right)(\mathrm{mgP} / \mathrm{L})$ & $0.5-1$ & $<0.5$ & $1.5-3.5$ \\
sulphates $\left(\mathrm{SO}_{4}{ }^{2-}\right)(\mathrm{mg} / \mathrm{L})$ & $150-300$ & $150-300$ & $150-300$ \\
chlorides $\left(\mathrm{Cl}^{-}\right)(\mathrm{mg} / \mathrm{L})$ & $300-400$ & $300-400$ & $500-700$ \\
Fe $(\mathrm{mg} / \mathrm{L})$ & $1.5-2.5$ & $<0.1$ & $0.2-0.5$ \\
Mn $(\mathrm{mg} / \mathrm{L})$ & $1.5-2.5$ & $<0.1$ & $0.2-0.5$ \\
\hline
\end{tabular}


Table 4. Changes of the water characteristics through the MBR-NF plant.

\begin{tabular}{|c|c|c|c|c|c|c|}
\hline \multirow[b]{2}{*}{ Water characteristics } & \multirow[b]{2}{*}{$\begin{array}{l}\text { MBR } \\
\text { feed }\end{array}$} & \multirow[b]{2}{*}{$\begin{array}{c}\text { MBR } \\
\text { permeate }\end{array}$} & \multirow[b]{2}{*}{$\begin{array}{c}\mathrm{NF} \\
\text { permeate }\end{array}$} & \multicolumn{3}{|c|}{ Removal efficiency (\%) } \\
\hline & & & & Total & MBR & $\mathrm{NF}$ \\
\hline $\mathrm{pH}$ & $7.7 \pm 0.13$ & $7.8 \pm 0.26$ & $6.9 \pm 0.40$ & - & - & - \\
\hline Conductivity $(\mu \mathrm{S} / \mathrm{cm})$ & $1930 \pm 320$ & $2175 \pm 63$ & $709 \pm 282$ & - & 67.4 & - \\
\hline COD $(\mathrm{mg} / \mathrm{L})$ & & & & & & \\
\hline raw water sample & $137 \pm 62$ & $16.7 \pm 4.8$ & $1.96 \pm 1.73$ & 87.8 & 88.2 & 98.6 \\
\hline TSS (mg/L) & $55.1 \pm 43.5$ & $3.2 \pm 3.5$ & negligible & 94.2 & $\sim 100$ & $\sim 100$ \\
\hline Inorganic nitrose $(\mathrm{mgN} / \mathrm{L})$ & & & & & & \\
\hline Nitrite & n.d. & $0.02 \pm 0.04$ & $0.01 \pm 0.003$ & - & 50.0 & - \\
\hline Nitrate & n.d. & $17.8 \pm 6.9$ & $15.3 \pm 3.1$ & - & 14.0 & - \\
\hline Ammonium & $30.1 \pm 10.4$ & $0.14 \pm 0.13$ & $0.05 \pm 0.03$ & 99.6 & 37.5 & 99.7 \\
\hline Hardness $\left({ }^{\circ} \mathrm{F}\right)$ & & & & & & \\
\hline total & n.d. & $41.2 \pm 8.1$ & $13.6 \pm 5.3$ & - & 67.7 & - \\
\hline permanent & n.d. & $19.3 \pm 3.4$ & $6.5 \pm 10.41 .5$ & - & 66.3 & - \\
\hline $\begin{array}{c}\text { phosphates }\left(\mathrm{P}-\mathrm{PO}_{4}{ }^{3-}\right) \\
(\mathrm{mgP} / \mathrm{L})\end{array}$ & $2.3 \pm 0.7$ & $2.1 \pm 0.5$ & $0.05 \pm 0.05$ & 8.6 & 97.6 & 97.8 \\
\hline sulphates $\left(\mathrm{SO}_{4}{ }^{2-}\right)(\mathrm{mg} / \mathrm{L})$ & $69 \pm 14$ & $94.8 \pm 41.5$ & $3.1 \pm 2.3$ & - & 96.7 & - \\
\hline chlorides $\left(\mathrm{Cl}^{-}\right)(\mathrm{mg} / \mathrm{L})$ & $206 \pm 71$ & $173 \pm 90$ & $143 \pm 58$ & 16 & 17.3 & 30.0 \\
\hline $\mathrm{Fe}(\mu \mathrm{g} / \mathrm{L})$ & $111 \pm 12$ & $45.9 \pm 25$ & $18 \pm 5$ & 59 & 61 & 84 \\
\hline $\operatorname{Mn}(\mu \mathrm{g} / \mathrm{L})$ & $85.4 \pm 15$ & $7.2 \pm 2.8$ & $5.7 \pm 1.2$ & 92 & 21 & 93 \\
\hline
\end{tabular}

* unfiltered sample 
Table 5. Physical tests results of the chrome-tanned leather.

\begin{tabular}{|c|c|c|c|c|c|c|c|c|c|}
\hline \multirow{2}{*}{$\begin{array}{l}\text { Tanning/Retanning } \\
\text { Type of water }\end{array}$} & \multicolumn{4}{|c|}{ Chrome/Chrome } & \multicolumn{4}{|c|}{ Chrome/Vegetable } & \multirow{2}{*}{$\begin{array}{l}\text { UNI } 10594 \\
\text { guidelines }\end{array}$} \\
\hline & $\mathrm{G} / \mathrm{G}$ & $\mathrm{G} / \mathrm{T}$ & $\mathrm{T} / \mathrm{G}$ & $\mathrm{T} / \mathrm{T}$ & $\mathrm{G} / \mathrm{G}$ & $\mathrm{G} / \mathrm{T}$ & $\mathrm{T} / \mathrm{G}$ & $\mathrm{T} / \mathrm{T}$ & \\
\hline Elongation at tear (mm) & 45.3 & 45.1 & 47.6 & 48.8 & 48.2 & 48.8 & 49.3 & 49.0 & - \\
\hline Tearing load $(\mathrm{N})$ & 108.9 & 108.1 & 107.1 & 110.0 & 112.3 & 112.9 & 114.2 & 123.5 & $30-80^{*}$ \\
\hline Tearing load/thickness (N/mm) & 74.6 & 76.1 & 77.6 & 82.1 & 72.5 & 73.8 & 74.2 & 79.2 & \\
\hline Distension at grain crack (mm) & 8.1 & 8.6 & 8.6 & 9.3 & 8.5 & 8.7 & 8.7 & 9.7 & $\geq 7$ \\
\hline Load at grain crack $(\mathrm{N})$ & 361.3 & 384.9 & 385.5 & 345.6 & 297.1 & 320.0 & 323.8 & 390.3 & $150-200$ \\
\hline Extension at break (mm) & 10.2 & 10.8 & 11.8 & 11.1 & 11.9 & 11.8 & 12.2 & 13.1 & - \\
\hline Load at break (N) & 506.8 & 609.4 & 572.5 & 575.0 & 637.6 & 641.9 & 730.3 & 705.6 & - \\
\hline
\end{tabular}

"Depending on the end use.

Table 6. Physical tests results of the vegetable-tanned leather.

\begin{tabular}{|c|c|c|c|c|c|c|c|c|c|}
\hline \multirow{2}{*}{$\begin{array}{c}\text { Tanning/Retanning } \\
\text { Type of water }\end{array}$} & \multicolumn{4}{|c|}{ Vegetable/Vegetable } & \multicolumn{4}{|c|}{ Vegetable/Syntan } & \multirow[t]{2}{*}{$\begin{array}{c}\text { UNI } \\
10594 \\
\text { guidelines }\end{array}$} \\
\hline & $\mathrm{G} / \mathrm{G}$ & $\mathrm{G} / \mathrm{T}$ & $\mathrm{T} / \mathrm{G}$ & $\mathrm{T} / \mathrm{T}$ & $\mathrm{G} / \mathrm{G}$ & $\mathrm{G} / \mathrm{T}$ & $\mathrm{T} / \mathrm{G}$ & $\mathrm{T} / \mathrm{T}$ & \\
\hline Elongation at tear (mm) & 42.0 & 41.8 & 41.9 & 42.0 & 42.2 & 39.1 & 43.2 & 41.2 & - \\
\hline Tearing load $(\mathrm{N})$ & 139.9 & 142.3 & 152.3 & 139.7 & 142.6 & 135.2 & 117.3 & 120.9 & $30-80^{*}$ \\
\hline Tearing load/thickness $(\mathrm{N} / \mathrm{mm})$ & 97.8 & 93.6 & 88.0 & 85.7 & 89.1 & 87.2 & 78.2 & 75.1 & \\
\hline Distension at grain crack (mm) & 7.6 & 7.0 & 6.9 & 6.4 & 8.3 & 8.0 & 6.9 & 6.8 & $\geq 7$ \\
\hline Load at grain crack $(\mathrm{N})$ & 497.2 & 449.7 & 270.2 & 213.7 & 502.9 & 431.2 & 337.7 & 218.5 & $150-200$ \\
\hline Extension at break (mm) & 9.2 & 8.9 & 10.4 & 9.6 & 9.9 & 9.5 & 9.1 & 10.5 & - \\
\hline Load at break $(\mathrm{N})$ & 775.0 & 720.9 & 724.0 & 664.7 & 705.9 & 675.5 & 594.1 & 666.5 & - \\
\hline
\end{tabular}

${ }^{*}$ Depending on the end use. 
Table 7. Technical properties of the chrome-tanned leather $(1=$ Poor $2=$ Fair $3=$ Good $4=$ Very Good 5 = Excellent).

\begin{tabular}{|l|cc|cc|cc|cc|}
\hline \multicolumn{1}{|r|}{$\begin{array}{r}\text { Tanning/Retanning } \\
\text { Type of water }\end{array}$} & \multicolumn{4}{|c|}{ Chrome/Chrome } & \multicolumn{4}{c|}{ Chrome/Vegetable } \\
& $\mathrm{G} / \mathrm{G}$ & $\mathrm{G} / \mathrm{T}$ & $\mathrm{T} / \mathrm{G}$ & $\mathrm{T} / \mathrm{T}$ & $\mathrm{G} / \mathrm{G}$ & $\mathrm{G} / \mathrm{T}$ & $\mathrm{T} / \mathrm{G}$ & $\mathrm{T} / \mathrm{T}$ \\
\hline Hand & $3 / 4$ & $3 / 4$ & $3 / 4$ & $3 / 4$ & 3 & $3 / 4$ & $3 / 4$ & 4 \\
\hline Roundness & $2 / 3$ & $2 / 3$ & $2 / 3$ & $2 / 3$ & $2 / 3$ & 3 & $2 / 3$ & 3 \\
\hline Fullness & $2 / 3$ & $2 / 3$ & $2 / 3$ & $2 / 3$ & 3 & 3 & 3 & 3 \\
Penetration & 2 & 2 & 2 & 2 & 2 & 2 & 2 & 2 \\
\hline Intensity & 3 & 3 & 3 & 3 & 3 & 3 & 3 & 3 \\
\hline Colour levelness & $3 / 4$ & $2 / 3$ & $2 / 3$ & $2 / 3$ & $2 / 3$ & $2 / 3$ & $2 / 3$ & $2 / 3$ \\
\hline
\end{tabular}

Table 8 . Technical properties of the vegetable-tanned leather $(1=$ Poor $2=$ Fair $3=$ Good $4=$ Very Good 5 = Excellent).

\begin{tabular}{|l|cc|cc|cc|cc|}
\hline \multicolumn{1}{|r|}{$\begin{array}{r}\text { Tanning/Retanning } \\
\text { Type of water }\end{array}$} & \multicolumn{4}{|c|}{ Chrome/Chrome } & \multicolumn{4}{c|}{ Chrome/Vegetable } \\
& $\mathrm{G} / \mathrm{G}$ & $\mathrm{G} / \mathrm{T}$ & $\mathrm{T} / \mathrm{G}$ & $\mathrm{T} / \mathrm{T}$ & $\mathrm{G} / \mathrm{G}$ & $\mathrm{G} / \mathrm{T}$ & $\mathrm{T} / \mathrm{G}$ & $\mathrm{T} / \mathrm{T}$ \\
\hline Hand & $3 / 4$ & $3 / 4$ & $3 / 4$ & $3 / 4$ & 3 & $3 / 4$ & $3 / 4$ & 4 \\
\hline Roundness & $2 / 3$ & $2 / 3$ & $2 / 3$ & $2 / 3$ & $2 / 3$ & 3 & $2 / 3$ & 3 \\
\hline Fullness & $2 / 3$ & $2 / 3$ & $2 / 3$ & $2 / 3$ & 3 & 3 & 3 & 3 \\
Penetration & 2 & 2 & 2 & 2 & 2 & 2 & 2 & 2 \\
\hline Intensity & 3 & 3 & 3 & 3 & 3 & 3 & 3 & 3 \\
\hline Colour levelness & $3 / 4$ & $2 / 3$ & $2 / 3$ & $2 / 3$ & $2 / 3$ & $2 / 3$ & $2 / 3$ & $2 / 3$ \\
\hline
\end{tabular}


Table 9. Physical and technical properties of the final leathers obtained on industrial scale.

\begin{tabular}{|c|c|c|}
\hline Water & $\mathrm{G} / \mathrm{G}$ & $\mathrm{T} / \mathrm{T}$ \\
\hline Thickness (mm) & 1.5 & 1.5 \\
\hline Elongation at tear (mm) & 40.7 & 41.6 \\
\hline Tearing load $(\mathrm{N})$ & 139.2 & 135.1 \\
\hline Distension at grain crack (mm) & 8.7 & 8.0 \\
\hline Load at grain crack $(\mathrm{N})$ & 371.6 & 318.4 \\
\hline Extension at break (mm) & 12.1 & 11.3 \\
\hline Load at break $(\mathrm{N})$ & 729.8 & 644.5 \\
\hline Hand & 5 & 5 \\
\hline Roundness & $3 / 4$ & 4 \\
\hline Fullness & 5 & 5 \\
\hline
\end{tabular}




\section{Appendix 1: Soaking and unhairing procedure}

Raw material: Salted raw calfskins ( $\%$ on salted raw weight).

\begin{tabular}{|c|c|c|c|}
\hline$\%$ & Product & Duration & \\
\hline 200 & Water $25^{\circ} \mathrm{C}$ & & \\
\hline 0.2 & Antibacterial & & \\
\hline 0.1 & Soaking surfactant & $40 \mathrm{~min}$ & $\begin{array}{l}\text { pH 7-8; } 30 \text { min stop. } \\
\text { Drain in drumming }\end{array}$ \\
\hline 100 & Water $26^{\circ} \mathrm{C}$ & & \\
\hline 0.5 & MgO-based basifying agent & & \\
\hline 0.2 & $\begin{array}{l}\text { Polifosphates-based } \\
\text { sequestrating agent }\end{array}$ & & \\
\hline 0.3 & Antibacterial & & \\
\hline 0.2 & Degreasing surfactant & $40 \mathrm{~min}$ & $\begin{array}{l}\text { Automatic drumming } \\
\text { overnight } \\
(5 \text { min of rotation } / \mathrm{h})\end{array}$ \\
\hline & & & $\begin{array}{l}\text { Morning check: T } 23-25^{\circ} \mathrm{C} \text {, } \\
\text { pH 9-10, density } 4-7^{\circ} \text { Bé }\end{array}$ \\
\hline $\begin{array}{l}0.1 \\
5\end{array}$ & Soaking enzyme & & \\
\hline 0.5 & MgO-based basifying agent & $1 \mathrm{~h}$ & \\
\hline 2 & Anti wrinkle & & \\
\hline $\begin{array}{l}0.1 \\
5 \\
\end{array}$ & Unhairing enzyme & $30 \mathrm{~min}$ & \\
\hline 1.5 & Sodium hydrosulphide & & \\
\hline 2.8 & Sodium sulphide & & \\
\hline $1 *$ & Lime & $90 \mathrm{~min}$ & 30 min stop \\
\hline $3 *$ & Lime & & \\
\hline 0.2 & $\begin{array}{l}\text { Polifosphates-based } \\
\text { sequestrating agent }\end{array}$ & $1 \mathrm{~h}$ & $\begin{array}{l}\text { Automatic drumming } \\
\text { overnight } \\
(5 \mathrm{~min} \text { of rotation } / \mathrm{h})\end{array}$ \\
\hline & & & $\begin{array}{l}\text { Morning check: } \mathrm{T} 25-28^{\circ} \mathrm{C} \text {, } \\
\text { pH } 12-13 \text {. } \\
\text { Drain in drumming }\end{array}$ \\
\hline 200 & Water $26^{\circ} \mathrm{C}$ & & \\
\hline 0.2 & $\begin{array}{l}\text { Polifosphates-based } \\
\text { sequestrating agent }\end{array}$ & $15 \mathrm{~min}$ & Drain, unload and flesh \\
\hline
\end{tabular}

* Dosage adopted for the chromium tanning process, twice as much was applied for the vegetable tanning process 
Appendix 2: Deliming, bating,pickling and chromium tanning procedure

Raw material: fleshed calfskins ( $\%$ on fleshed weight).

\begin{tabular}{|c|c|c|c|}
\hline$\%$ & Product & $\begin{array}{l}\text { Duratio } \\
\mathrm{n}\end{array}$ & \\
\hline 200 & Water $35^{\circ} \mathrm{C}$ & & \\
\hline 0.2 & Oxalic acid $(1: 15 \mathrm{w} / \mathrm{w})$ & & \\
\hline 0.1 & Surfactant degreaser & $10 \mathrm{~min}$ & $\mathrm{pH} 10-10.5$. Drain \\
\hline 150 & Water $35^{\circ} \mathrm{C}$ & $5 \mathrm{~min}$ & Drain \\
\hline 80 & Water $35^{\circ} \mathrm{C}$ & & \\
\hline 0.2 & Surfactant degreaser & & \\
\hline 1 & Ammonium sulfate & $15 \mathrm{~min}$ & \\
\hline 1 & Ammonium sulfate & $20 \mathrm{~min}$ & $\mathrm{pH} \mathrm{8.0/8.5} \mathrm{bath} \mathrm{and} \mathrm{section}$ \\
\hline 0.5 & Deliming mix & & \\
\hline 0.5 & Bating agent & $25 \mathrm{~min}$ & Bating check. Drain \\
\hline 300 & Acqua $20^{\circ} \mathrm{C}$ & $10 \mathrm{~min}$ & Drain \\
\hline 50 & Water $20^{\circ} \mathrm{C}$ & & \\
\hline 8 & Sodium chloride & & \\
\hline 1 & $\begin{array}{l}\text { Sodium chlorite (solution } \\
21 \% \mathrm{w} / \mathrm{w} \text { ) }\end{array}$ & & \\
\hline 0.2 & $\begin{array}{l}\text { EDTA-based sequestering } \\
\text { agent }\end{array}$ & & \\
\hline 0.1 & Fatliquor & $15 \mathrm{~min}$ & Density check $8-9^{\circ}$ Bè \\
\hline 0.5 & Formic acid $(1: 10 \mathrm{w} / \mathrm{w})$ & $30 \mathrm{~min}$ & Slow drumming \\
\hline 1.6 & Sulphuric acid $(1: 20 \mathrm{w} / \mathrm{w})$ & $4 \mathrm{~h}$ & $\begin{array}{l}\text { Slow drumming. Automatic drumming } \\
\text { overnight } \\
(5 \text { min of rotation } / \mathrm{h})\end{array}$ \\
\hline & & & $\begin{array}{l}\text { Morning check pH } 2.6-2.8 \text { (yellow } \\
\text { section after bromine cresol test) }\end{array}$ \\
\hline 0.2 & Sodium formate & $15 \mathrm{~min}$ & Drain half float \\
\hline 4.5 & $\begin{array}{l}\text { Basic chromium sulfate } \\
\text { (26\% Cr2O3-33\% basicity) }\end{array}$ & & \\
\hline 0.1 & $\begin{array}{l}\text { EDTA-based sequestering } \\
\text { agent }\end{array}$ & & \\
\hline 0.1 & Fatliquor & $30 \mathrm{~min}$ & \\
\hline 0.1 & Anti-mould agent & $90 \mathrm{~min}$ & \\
\hline 4.5 & $\begin{array}{l}\text { Basic chromium sulfate } \\
(26 \% \text { Cr2O3-33\% basicity) }\end{array}$ & & \\
\hline 0.05 & $\begin{array}{l}\text { EDTA-based sequestering } \\
\text { agent }\end{array}$ & & \\
\hline 0.5 & Sodium acetate $(1: 10 \mathrm{w} / \mathrm{w})$ & $4 \mathrm{~h}$ & Check chromium crossing \\
\hline 40 & Water $42^{\circ} \mathrm{C}$ & & \\
\hline \multirow[t]{2}{*}{1} & Magnesium oxide & $8 \mathrm{~h}$ & $\begin{array}{l}\text { Automatic drumming overnight } \\
(5 \mathrm{~min} \text { of rotation } / \mathrm{h})\end{array}$ \\
\hline & & & $\begin{array}{l}\text { Morning check: } \mathrm{T} 39-41^{\circ} \mathrm{C} \text {, pH } 3.6-3.7 \text {. } \\
\text { Drain }\end{array}$ \\
\hline 150 & Water $20^{\circ} \mathrm{C}$ & & \\
\hline 0.05 & Formic acid $(1: 10 \mathrm{w} / \mathrm{w})$ & $15 \mathrm{~min}$ & Drain. Pinning 24 h. Pressing, shaving. \\
\hline
\end{tabular}


Appendix 3: Chromium tannage: chromium retanning, dyeing, fatliquoring procedure

Raw material: shaved chromium tanned calfskins ( $\%$ on shaved weight).

\begin{tabular}{|c|c|c|c|}
\hline$\%$ & Product & Duration & \\
\hline 200 & Water $35^{\circ} \mathrm{C}$ & & \\
\hline 0.5 & Oxalic acid $(1: 15 \mathrm{w} / \mathrm{w})$ & & \\
\hline 0.5 & Degreasing surfactant & $40 \mathrm{~min}$ & Drain \\
\hline 70 & Water $35^{\circ} \mathrm{C}$ & & \\
\hline 4 & Chromium salts-syntans mixture & $15 \mathrm{~min}$ & \\
\hline \multirow[t]{2}{*}{6} & $\begin{array}{l}\text { Basic chromium sulfate } \\
\text { (26\% Cr2O3-33\% basicity) }\end{array}$ & $2 \mathrm{~h}$ & $\begin{array}{l}\text { Automatic drumming overnight } \\
(5 \mathrm{~min} \text { of rotation } / \mathrm{h})\end{array}$ \\
\hline & & & $\begin{array}{l}\text { Morning check: } \mathrm{pH} 4 \\
\text { Drain }\end{array}$ \\
\hline 100 & Water $35^{\circ} \mathrm{C}$ & & \\
\hline 0.5 & Sodium formate & $15 \mathrm{~min}$ & \\
\hline 0.5 & Sodium bicarbonate & $30 \mathrm{~min}$ & $\begin{array}{l}\text { section check (green/blue) } \\
\text { pH check }(4.6-4.8) \\
\text { Drain }\end{array}$ \\
\hline 200 & Water $35^{\circ} \mathrm{C}$ & $5 \mathrm{~min}$ & Drain \\
\hline 100 & Water $40^{\circ} \mathrm{C}$ & & \\
\hline 4 & Acrylic resin & $40 \mathrm{~min}$ & \\
\hline 4 & Syntan & & \\
\hline 4 & Melamminic resin & $1 \mathrm{~h}$ & \\
\hline 0.5 & Formic acid $(1: 10 \mathrm{w} / \mathrm{w})$ & $20 \mathrm{~min}$ & Drain \\
\hline 50 & Water $20^{\circ} \mathrm{C}$ & & \\
\hline 3.5 & Dye & $40 \mathrm{~min}$ & Section check \\
\hline 150 & Water $50^{\circ} \mathrm{C}$ & & \\
\hline 3.5 & Formic acid $(1: 10)$ & $30 \mathrm{~min}$ & Drain \\
\hline 150 & Water $50^{\circ} \mathrm{C}$ & & \\
\hline 5.5 & $\begin{array}{l}\text { Vegetable fatliquors/syntans } \\
\text { mixture }\end{array}$ & $1 \mathrm{~h}$ & \\
\hline 0.5 & Formic acid $(1: 10 \mathrm{w} / \mathrm{w})$ & $20 \mathrm{~min}$ & $\begin{array}{l}\text { Fatliquor exhaustion check } \\
\text { Drain }\end{array}$ \\
\hline 150 & Water $50^{\circ} \mathrm{C}$ & & \\
\hline 3.5 & Dye & $20 \mathrm{~min}$ & \\
\hline 1.8 & Formic acid $(1: 10 \mathrm{w} / \mathrm{w})$ & $20 \mathrm{~min}$ & Drain \\
\hline 1.8 & Formic acid 1:10 w/w) & $20 \mathrm{~min}$ & \\
\hline 200 & Water $20^{\circ} \mathrm{C}$ & $10 \mathrm{~min}$ & Drain and unload \\
\hline
\end{tabular}




\section{Appendix 4: Chromium tannage: vegetable retanning, dyeing, fatliquoring procedure}

Raw material: shaved chromium tanned calfskins ( $\%$ on shaved weight).

\begin{tabular}{|c|c|c|c|}
\hline$\%$ & Product & Duration & \\
\hline 200 & Water $35^{\circ} \mathrm{C}$ & & \\
\hline 0.5 & Oxalic acid $(1: 15 \mathrm{w} / \mathrm{w})$ & & \\
\hline 0.5 & Degreasing surfactant & $40 \mathrm{~min}$ & Drain \\
\hline 70 & Water $35^{\circ} \mathrm{C}$ & & \\
\hline 4 & Chromium salts-syntans mixture & $15 \mathrm{~min}$ & \\
\hline 6 & $\begin{array}{l}\text { Basic chromium sulfate } \\
(26 \% \text { Cr2O3-33\% basicity) }\end{array}$ & $2 \mathrm{~h}$ & $\begin{array}{l}\text { Automatic drumming } \\
\text { overnight } \\
(5 \mathrm{~min} \text { of rotation } / \mathrm{h})\end{array}$ \\
\hline & & & $\begin{array}{l}\text { Morning check: } \mathrm{pH} 4 \\
\text { Drain }\end{array}$ \\
\hline 200 & Water $35^{\circ} \mathrm{C}$ & $5 \mathrm{~min}$ & \\
\hline 100 & Water $35^{\circ} \mathrm{C}$ & & \\
\hline 0.5 & Sodium formate & $15 \mathrm{~min}$ & \\
\hline 0.5 & Sodium acetate & $10 \mathrm{~min}$ & \\
\hline 0.7 & Sodium bicarbonate & $30 \mathrm{~min}$ & $\begin{array}{l}\mathrm{pH} \text { check through section } \\
\text { Drain }\end{array}$ \\
\hline 150 & Water $35^{\circ} \mathrm{C}$ & $5 \min$ & Drain \\
\hline 100 & Water $40^{\circ} \mathrm{C}$ & & \\
\hline 4 & Acrylic resin & $40 \mathrm{~min}$ & \\
\hline 2 & Cchestnut N2 extract & & \\
\hline 2 & Quebracho ATO extract & & \\
\hline 2 & Dicyandiammidic resin & & \\
\hline 4 & Syntan & $90 \mathrm{~min}$ & \\
\hline 0.5 & Formic acid $(1: 10 \mathrm{w} / \mathrm{w})$ & $20 \mathrm{~min}$ & Drain \\
\hline 100 & Water $40^{\circ} \mathrm{C}$ & & \\
\hline 3 & Dye & $40 \mathrm{~min}$ & Section check \\
\hline 3 & Formic acid $(1: 10 \mathrm{w} / \mathrm{w})$ & $30 \mathrm{~min}$ & Drain \\
\hline 100 & Water $40^{\circ} \mathrm{C}$ & $5 \mathrm{~min}$ & \\
\hline 100 & Water $50^{\circ} \mathrm{C}$ & & \\
\hline 6 & $\begin{array}{l}\text { Mixture of synthetic and natural } \\
\text { fatliquors }\end{array}$ & & \\
\hline 0.5 & Emulsifier & $1 \mathrm{~h}$ & \\
\hline 0.5 & Formic acid $(1: 10 \mathrm{w} / \mathrm{w})$ & $30 \mathrm{~min}$ & $\begin{array}{l}\text { Fatliquor exhaustion check } \\
\text { Drain }\end{array}$ \\
\hline 200 & Water $20^{\circ} \mathrm{C}$ & $10 \mathrm{~min}$ & Drain and unload \\
\hline
\end{tabular}


Appendix 5: Deliming, bating,pickling and vegetable tanning procedure Raw material: fleshed calfskins ( $\%$ on fleshed weight).

\begin{tabular}{|c|c|c|c|}
\hline$\%$ & Product & Duration & \\
\hline 150 & Water $35^{\circ} \mathrm{C}$ & & \\
\hline 0.2 & Oxalic acid $(1: 15 \mathrm{w} / \mathrm{w})$ & & \\
\hline 0.1 & Surfactant degreaser & $10 \mathrm{~min}$ & pH 10-10.5. Drain \\
\hline 150 & Water $35^{\circ} \mathrm{C}$ & $5 \mathrm{~min}$ & Drain \\
\hline 80 & Water $35^{\circ} \mathrm{C}$ & & \\
\hline 0.2 & Surfactant degreaser & & \\
\hline 1.8 & Ammonium sulfate & $15 \mathrm{~min}$ & \\
\hline 1.8 & Ammonium sulfate & $15 \mathrm{~min}$ & $\mathrm{pH} \mathrm{8.0/8.5} \mathrm{bath} \mathrm{and} \mathrm{section}$ \\
\hline 0.5 & Bating agent & $25 \mathrm{~min}$ & Bating check. Drain \\
\hline 150 & Water $20^{\circ} \mathrm{C}$ & & Wash and drain \\
\hline 150 & Water $20^{\circ} \mathrm{C}$ & & Wash and drain \\
\hline 50 & Water $20^{\circ} \mathrm{C}$ & & \\
\hline 8 & Sodium chloride & & \\
\hline 1 & Sodium chlorite & & \\
\hline 0.2 & $\begin{array}{l}\text { EDTA-based sequestering } \\
\text { agent }\end{array}$ & & \\
\hline 0.1 & Fatliquor & $15 \mathrm{~min}$ & Density check $8-9^{\circ}$ Bè \\
\hline 0.5 & Formic acid $(1: 10 \mathrm{w} / \mathrm{w})$ & $30 \mathrm{~min}$ & Slow drumming \\
\hline 0.8 & Sulphuric acid $(1: 20 \mathrm{w} / \mathrm{w})$ & $4 \mathrm{~h}$ & $\begin{array}{l}\text { Slow drumming. Automatic } \\
\text { drumming overnight } \\
(5 \mathrm{~min} \text { of rotation } / \mathrm{h})\end{array}$ \\
\hline & & & Morning check pH 3.2 \\
\hline 3 & Pre-tanning syntan & $2 \mathrm{~h}$ & Drain \\
\hline 10 & Quebracho ATO extract & & \\
\hline 3 & Chestnut $\mathrm{N}$ extract & & \\
\hline 2 & Chestnut N2 extract & $90 \mathrm{~min}$ & \\
\hline 10 & Quebracho ATO extract & & \\
\hline 3 & Chestnut extract & & \\
\hline 2 & Sweetened chestnut extract & & \\
\hline 1 & Sulphited fish oil & & \\
\hline 1 & Dicyandiammidic resin & $2 \mathrm{~h}$ & \\
\hline 30 & Water $37^{\circ} \mathrm{C}$ & $8 \mathrm{~h}$ & $\begin{array}{l}\text { Automatic drumming } \\
\text { overnight } \\
\text { ( } 5 \text { min of rotation } / \mathrm{h})\end{array}$ \\
\hline & & & Morning section check \\
\hline 150 & Water $37^{\circ} \mathrm{C}$ & & \\
\hline 1 & Oxalic acid $(1: 15 \mathrm{w} / \mathrm{w})$ & $30 \mathrm{~min}$ & Drain and unload \\
\hline
\end{tabular}


Appendix 6: Vegetable tannage: vegetable retanning, dyeing, fatliquoring procedure

Raw material: shaved vegetable tanned calfskins (\% on shaved weight).

\begin{tabular}{|c|c|c|c|}
\hline$\%$ & Product & Duration & \\
\hline 200 & Water $30^{\circ} \mathrm{C}$ & & \\
\hline 1 & Oxalic acid $(1: 15 \mathrm{w} / \mathrm{w})$ & $30 \mathrm{~min}$ & Stains check and drain \\
\hline 300 & Water $30^{\circ} \mathrm{C}$ & $10 \mathrm{~min}$ & Wash and drain \\
\hline 15 & Water $20^{\circ} \mathrm{C}$ & & \\
\hline 3 & Quebracho ATO extract & & \\
\hline 1 & Sumach extract & & \\
\hline 2 & Syntan & & \\
\hline 1.5 & Dye & & \\
\hline 1 & Dicyandiammidic resin & & \\
\hline \multirow[t]{2}{*}{0.5} & Sulphited fish oil & $6 \mathrm{~h}$ & $\begin{array}{l}\text { Automatic drumming overnight } \\
(5 \mathrm{~min} \text { of rotation } / \mathrm{h} \text { ) }\end{array}$ \\
\hline & & & $\begin{array}{l}\text { Morning check section } \\
\text { penetration }\end{array}$ \\
\hline 100 & Water $35^{\circ} \mathrm{C}$ & $5 \mathrm{~min}$ & \\
\hline 1.5 & Formic acid $(1: 10 \mathrm{w} / \mathrm{w})$ & $1 \mathrm{~h}$ & Drain \\
\hline 100 & Water $40^{\circ} \mathrm{C}$ & & \\
\hline 4.5 & $\begin{array}{l}\text { Mixture of synthetic and natural } \\
\text { fatliquors }\end{array}$ & $1 \mathrm{~h}$ & \\
\hline 0.5 & Formic acid $(1: 10 \mathrm{w} / \mathrm{w})$ & $30 \mathrm{~min}$ & $\begin{array}{l}\text { Fatliquor exhaustion check } \\
\text { Drain }\end{array}$ \\
\hline 200 & Water $20^{\circ} \mathrm{C}$ & & \\
\hline 0.2 & Oxalic acid $/(1: 15 \mathrm{w} / \mathrm{w})$ & $15 \mathrm{~min}$ & Drain and unload \\
\hline
\end{tabular}


Appendix 7: Vegetable tannage: syntan retanning, dyeing, fatliquoring procedure Raw material: shaved vegetable tanned calfskins ( $\%$ on shaved weight).

\begin{tabular}{|l|l|l|l|}
\hline$\%$ & Product & Duration & \\
\hline 200 & Water $30^{\circ} \mathrm{C}$ & & \\
\hline 1 & Oxalic acid $(1: 15 \mathrm{w} / \mathrm{w})$ & $30 \mathrm{~min}$ & Stains check and drain \\
\hline 300 & Water $30^{\circ} \mathrm{C}$ & $10 \mathrm{~min}$ & Wash and drain \\
\hline 30 & Water $20^{\circ} \mathrm{C}$ & & \\
\hline 2 & Syntan & $20 \mathrm{~min}$ & \\
\hline 5 & Syntan & & \\
\hline 1 & Dicyandiammidic resin & $40 \mathrm{~min}$ & \\
\hline 1 & Olio di pesce solfitato & & \\
\hline 5 & Syntan & & \\
\hline 1 & Dicyandiammidic resin & $3 \mathrm{~h}$ & Check section penetration \\
\hline 1 & Sulphited fish oil & $10 \mathrm{~min}$ & \\
\hline 1.5 & Dye & $70 \mathrm{~min}$ & $\begin{array}{l}\text { Automatic drumming overnight } \\
(5 \text { min of rotation } / \mathrm{h})\end{array}$ \\
\hline 100 & Water $40^{\circ} \mathrm{C}$ & & Morning drain \\
\hline 1.5 & Formic acid $(1: 10 \mathrm{w} / \mathrm{w})$ & & \\
\hline & & $1 \mathrm{~h}$ & \\
\hline 100 & Water $45^{\circ} \mathrm{C}$ & $30 \mathrm{~min}$ & $\begin{array}{l}\text { Fatliquor exhaustion check } \\
\text { Drain }\end{array}$ \\
\hline 4.5 & $\begin{array}{l}\text { Mixture of synthetic and natural } \\
\text { fatliquors }\end{array}$ & & \\
\hline 0.5 & Formic acid $(1: 10 \mathrm{w} / \mathrm{w})$ & $15 \mathrm{~min}$ & Drain and unload \\
\hline 200 & Water $20^{\circ} \mathrm{C}$ & & \\
\hline 0.2 & Oxalic acid $/(1: 15 \mathrm{w} / \mathrm{w})$ & & \\
\hline
\end{tabular}

